\title{
Corpos sem órgãos versus cisheteronormatividade: os territórios do corpo nas artes, na sociedade e na escola
}

\section{Bodies without organs versus cisheteronormativity: the territories of the body in the arts, in society, and in school}

\section{Cuerpos sin órganos versus cisheteronormatividad: los territorios del cuerpo en las artes, en la sociedad y en la escuela}

Sabina Sebasti ${ }^{1}$

Ana Gabriela da Silva Vieira ${ }^{1}$

Márcio Caetano ${ }^{1}$

DOI: http://dx.doi.org/10.20435/serie-estudos.v26i58.1584

\begin{abstract}
Resumo: O corpo sem órgãos consiste em um conceito que, embora tenha surgido com o dramaturgo Artaud, foi desenvolvido por Deleuze e Guattari para discutir as possibilidades múltiplas de experimentação do corpo, para além da sua estratificação enquanto organismo. Este artigo implica uma reflexão sobre os territórios do corpo em manifestações contemporâneas das artes visuais, acerca de sua funcionalidade, seus espaços e seus condicionamentos. Entendese que a estratificação, a territorialização e a normalização dos corpos são perpassadas pelos desígnios da cisheteronormatividade, que exige deles determinadas condutas sexuais e de gênero. Considerando que a escola, conforme apontam as pesquisas de Foucault, representa uma instituição tradicionalmente voltada ao funcionamento da disciplina e da regulação dos corpos, tornando-os dóceis e aproximados da norma, nesse panorama, as artes, como campo de conhecimento, significam um caminho pedagógico para abordar e questionar os territórios do corpo, suas manifestações, assim como a multiplicidade inerente nele.
\end{abstract}

Palavras-chave: corpo sem órgãos; artes visuais; escola.

Abstract: The body without organs is a concept that, although it emerged with the playwright Artaud, was developed by Deleuze and Guattari to discuss the multiple possibilities of experimentation of the body beyond its stratification as an organism. This article implies a reflection on the territories

\footnotetext{
${ }^{1}$ Universidade Federal de Pelotas (UFPEL), Pelotas, Rio Grande do Sul, Brasil.
} 
of the body in contemporary manifestations of the visual arts, about its functionality, its spaces, and its conditioning. It is understood that the stratification, territorialization, and normalization of the bodies are crossed by the designs of cisheteronormativity, which demands from them certain sexual and gender behaviors. Considering that the school, according to Foucault's research, represents an institution traditionally directed to the functioning of discipline and regulation of bodies, making them docile and close to the norm; in this scenario, the arts, as a field of knowledge, mean a pedagogical path to approach and question the territories of the body, its manifestations, as well as the multiplicity inherent in it.

Keywords: body without organs; visual arts; school.

Resumen: El cuerpo sin órganos consiste en un concepto que, si bien surgió con el dramaturgo Artaud, fue desarrollado por Deleuze y Guattari para discutir las múltiples posibilidades de experimentación del cuerpo, más allá de su estratificación en cuanto organismo. Este artículo implica una reflexión sobre los territorios del cuerpo en manifestaciones contemporáneas de las artes visuales, acerca de su funcionalidad, sus espacios y sus condicionamientos. Se entiende que la estratificación, la territorialización y la normalización del cuerpo son atravesadas por los designios de la cisheteronormatividad, que exige de ellos determinadas conductas sexuales y de género. Considerando que la escuela, conforme apuntan las investigaciones de Foucault, representa una institución tradicionalmente dirigida al funcionamiento de la disciplina y de la regulación de los cuerpos, tornándolos dóciles y aproximados a la norma; en este panorama, las artes, como campo de conocimiento, significan un camino pedagógico para abordar y cuestionar los territorios del cuerpo, sus manifestaciones, así como la multiplicidad inherente en él.

Palabras clave: cuerpo sin órganos; artes visuales; escuela.

\section{INTRODUÇÃO}

Ao realizar esta escrita, envolvemos reflexões provocadas a partir de manifestações artísticas contemporâneas. Com elas, buscamos articular diálogos no campo dos estudos do corpo em suas intersecções com gênero e sexualidades, pensando que os discursos e as pedagogias proferidas pelos artefatos culturais interpelam os modos com que sujeitos se (re)afirmam em suas práticas, reinventando possibilidades contra-hegemônicas. Para isso, nós nos referenciamos nos Estudos Culturais em suas vertentes pós-estruturalistas.

Acreditamos que, muito mais que seduzir, as obras artísticas funcionam como artefatos culturais que tencionam saberes, formas de pensar e de produzir no e com o mundo. No âmbito da cultura, entendemos as pedagogias vinculadas nas obras artísticas, enquanto processos sociais que ensinam, investem e tencionam interesses, uma vez que os discursos instituídos por eles incidem e disputam os modos como as subjetividades se configuram, apontando formas de ser e de estar dos sujeitos. Assim sendo, a cultura é entendida enquanto uma arena de 
intensa disputa e acordo em que são (re)construídas posições, envolvendo diferentes marcadores de diferença. É nesse sentido que se propõem os debates neste artigo, pensando a potência de um corpo sem órgãos a partir das práticas de liberdade de gênero/sexualidade exercidas através da arte, e questionando - mais do que respondendo - de que forma essas práticas podem adentrar o espaço da escola.

Como nos assinala Marie-José Mondzain (2011, p. 106), “[...] quando a imagem não é uma coisa, ela provoca o advento de alguém". Em outras palavras, as obras em discussão produzem imagens que não são apenas reflexos de informações que circulam no sistema-mundo, mas expressam nos sujeitos que as olham, substanciados pelos seus processos educativos, opiniões e valores que engendram seus corpos. Na tentativa de perseguir e problematizar essas e outras questões, nós nos deslocamos entre as perspectivas dos Estudos Culturais que buscamos para pensar como essas obras artísticas (re)afirmam, movimentam e/ou deslocam assimetrias das perspectivas hegemônicas, nos múltiplos espaçostempos em que circulam os debates sobre o corpo.

São várias as temáticas que se configuram no território do corpo. Este artigo foi construído a seis mãos, no intuito de refletir acerca do corpo e suas possibilidades em diferentes âmbitos sociais ou, de forma mais específica, nas artes e na escola. Como aponta Michel Foucault (2018) em entrevista denominada Poder-Corpo, publicada em Microfísica do Poder, os mecanismos de poder em funcionamento em cada sociedade se exercem sobre os corpos das pessoas. Fazendo um adendo à teorização foucaultiana acerca do poder, que não seria puramente verticalizado ou repressivo, mas produtivo e presente em todas as relações sociais, importa explicitar, nesta perspectiva, que a própria consciência que se tem do corpo é possível a partir dos efeitos de poder que penetram nele. Nas relações cotidianas, o corpo entra em uma constante disputa nos diferentes contextos, sejam escolares, sejam médicos ou familiares.

As tecnologias disciplinares - que se fortificam no contexto histórico da Modernidade - agem diretamente sobre os corpos, para torná-los dóceis, considerando "[...] dócil um corpo que pode ser submetido, que pode ser utilizado, que pode ser transformado e aperfeiçoado" (FOUCAULT, 1997, p. 134). Isso não significa dizer que antes do século XVIII os corpos estavam livres de quaisquer investimentos do poder, mas que neste momento uma forma de poder, com estratégias 
específicas, passa a agir sobre os corpos dos indivíduos: a disciplina. Foucault (1997), em Vigiar e Punir, fala em uma política de coerção que esquadrinha o corpo, molda-o e o fabrica. As disciplinas funcionam de forma detalhada e constante em seu assujeitamento. As estratégias do poder disciplinar, além de demarcarem um investimento do corpo que é minucioso e político, também continuaram a se ampliar cada vez mais, buscando atingir todo o corpo social.

Dentre as características da disciplina, o filósofo argumenta que esta busca distribuir os sujeitos no espaço de determinados modos, o que por vezes implica inseri-los e cercá-los em uma instituição na qual o funcionamento das estratégias de poder podem se dar de forma mais acentuada, como é o caso dos quartéis militares, dos hospitais, das fábricas e também da escola da Modernidade, que, para Foucault, corresponderia aos séculos XVIII, XIXe XX-que é de interesse neste artigo. "Houve, durante a Época Clássica, uma descoberta do corpo como objeto e alvo do poder" (FOUCAULT, 1997, p. 134). O autor falava da crescente intensificação, na modernidade, das práticas disciplinares que operam sobre o corpo. "Muitos processos disciplinares existiam há muito tempo: nos conventos, nos exércitos, nas oficinas também. Mas as disciplinas se tornaram no decorrer dos séculos XVII e XVIII fórmulas gerais de dominação" (FOUCAULT, 1997, p. 135). Os corpos treinados, obedientes, modelados em seus movimentos e posturas para servir às instituições, para obedecer a ordens de forma eficiente, como resultado de processos disciplinares que começam já na escola, que os torna submissos, maleáveis e úteis.

Nos âmbitos escolares, através da organização do espaço físico, controlam-se e disciplinam os corpos: enfileirando, distribuindo grupos, adjudicando lugares, uma aula, uma cadeira, um lugar para cada um. Constitui-se "[...] o espaço escolar como uma máquina de ensinar, mas também de vigiar, de hierarquizar, de recompensar" (FOUCAULT, 1997, p. 144). Os processos disciplinares operam também através da organização dos tempos, dos horários das disciplinas, dos intervalos, da hora de ingresso e de saída, exigindo pontualidade, maximizando rendimentos. Em definitiva, como assinalava o pesquisador, são técnicas, procedimentos ou imposições que pretendem transformar "[...] as multidões confusas, inúteis ou perigosas em multiplicidades organizadas" (FOUCAULT, 1997, p. 145).

Assim, pode-se entender a escola como uma instituição social privilegiada para o exercício da disciplina, na medida em que fez e continua a fazer funcionar suas técnicas, atendendo à "[...] necessidade de vigiar, de romper as comunicações 
perigosas, mas também de criar um espaço útil" (FOUCAULT, 1997, p. 141). Não apenas nas instituições disciplinares - mas costumeiramente nelas - os corpos são hierarquizados, treinados, têm seu tempo estabelecido para o desenvolvimento de atividades, têm habilidades obrigatórias que Ihes são exigidas. Para o mesmo autor, a disciplina:

[...] constrói quadros; prescreve manobras; impõe exercícios; enfim, para realizar a combinação das forças, organiza táticas. A tática, arte de construir, com os corpos localizados, atividades codificadas e as aptidões formadas, aparelhos em que o produto das diferentes forças se encontra majorado por sua combinação calculada é sem dúvida a forma mais elevada da prática disciplinar. (FOUCAULT, 1997, p. 164).

Além das tecnologias disciplinares, também fazem parte da sociedade ocidental as tecnologias biopolíticas, cuja atuação não é tanto sobre os corpos dos indivíduos, mas sobre os corpos que formam as populações. Foucault (2010), no curso Em Defesa da Sociedade, chama de biopolítica a regulamentação enquanto um problema político e também biológico, ou seja, enquanto espécie; assim, lança-se mão das estatísticas para medir e buscar equilíbrio nos dados populacionais. No contexto da escola, isso pode ser pensado a partir das políticas públicas e estabelecimento de documentos curriculares de nível nacional, estadual ou municipal, que regulam o espaço da escola.

Dentre as normas que as tecnologias disciplinares e biopolíticas fazem funcionar, pode-se ressaltar a heteronormatividade, de forma imbricada à cisgeneronormatividade. Assim, na escola e em outros espaços sociais, os corpos são disciplinados e regulados de forma de se encaixarem nesta norma, para atenderem aos desígnios de um sexo dito biológico e apresentarem uma conduta de acordo com este - conduta que, cabe ressaltar, inclui uma sexualidade hétero.

Isso não quer dizer, no entanto, que o exercício do poder sobre o corpo deva ser visto de forma determinista, já que, para Foucault (2010), embora não haja espaço no qual o poder está ausente, também não existe espaço ausente de resistência. A resistência e o poder, na teorização foucaultiana, ao contrário de estarem em oposição, estão em uma relação de interdependência. Os corpos, dessa forma, mesmo que não possam escapar completamente ao poder, podem resistir, podem - no âmbito das relações cotidianas - forjar suas liberdades de vários modos, inclusive através da arte. 


\section{O CORPO SEM ÓRGÃOS}

No ano de 1966, inaugurava-se no Museu de Arte Moderna de Estocolmo a escultura-instalação Ela-uma Catedral, da artista francesa Niki de Saint Phalle. O corpo de Ela, uma estrutura de metal revestida com telas coladas umas sobre as outras e finalmente pintadas, consistia em uma monumental escultura oca (Figura 1). A artista batizou a instalação de Hon in Katedral, que em sueco significa: ela, uma catedral. A obra era um enorme corpo de mulher grávida, de 23 metros de largura por 13 metros de comprimento e 14 metros de altura, deitada de costas, de pernas abertas, com os joelhos levantados, e no lugar da vagina, uma porta ou orifício oval, através do qual o público ingressava ao interior. Dentro dela não se achavam órgãos, mas um recinto quente e escuro que funcionava como um pequeno parque de diversões, com diferentes atrações, entre elas um planetário, uma galeria com quadros, uma pequena sala de cinema, um quiosque, um aquário com peixes, um telefone e algumas instalações de arte.

Figura 1 - Escultura-instalação She - a Cathedral (Ela - uma Catedral)

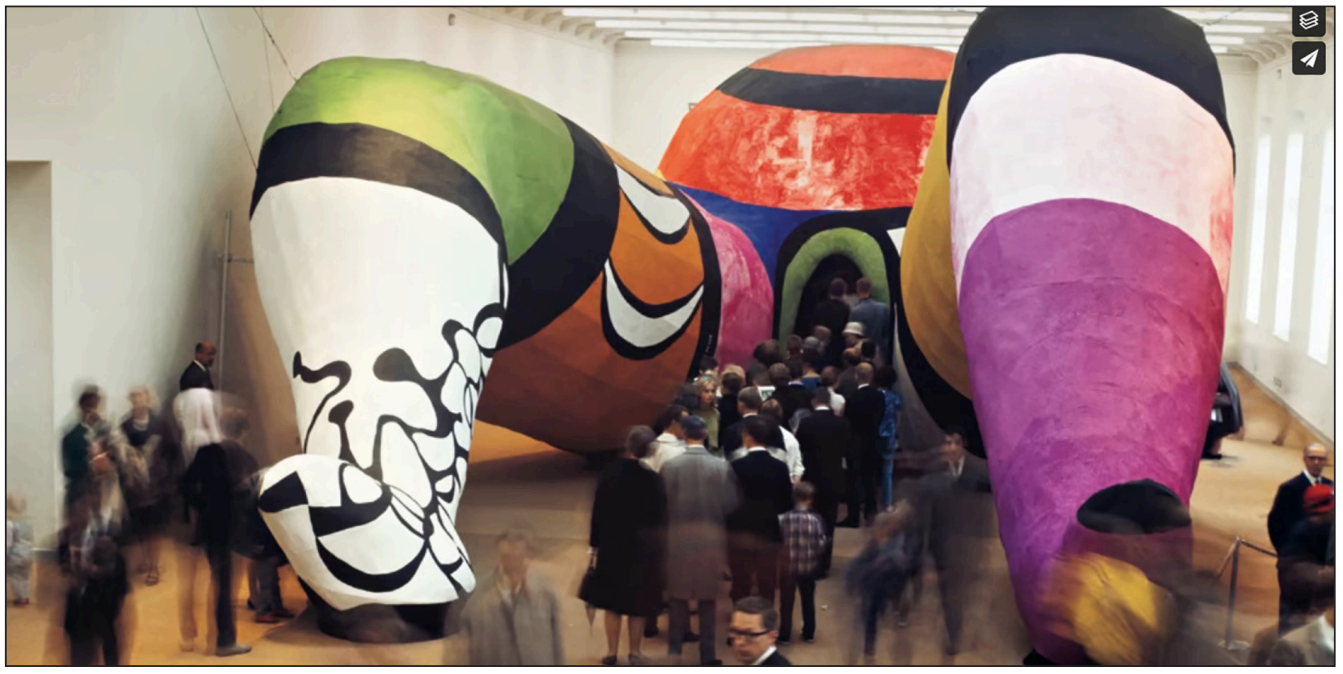

Fonte: Captura de vídeo, exibição de She - a Cathedral / Hon - em Katedral, Museu de Arte Moderna de Estocolmo, 1966. Disponível em https://vimeo.com/172405445

O Museu de Arte Moderna de Estocolmo tinha disposto uma enorme sala para que a equipe composta por três artistas pudesse realizar a obra. Para evitar 
qualquer tipo de censura - que felizmente não aconteceu -, os três trabalharam de portas fechadas durante a montagem. Afinal, mais de cem mil pessoas, entre adultos e crianças, entraram na gigantesca instalação durante os três meses que durou a exposição.

A temática do corpo feminino foi amplamente explorada por Niki nas suas esculturas de Noivas, Alumbramentos, Deusas e Mães Devoradoras, precursoras de um trabalho que culminaria na sua série Nanas: corpos femininos erguidos à força de arame, papel e resina, coloridos, resistentes, voluptuosos, enormes, pois, como dizia Niki, elas deviam ser ainda maiores para poder serem iguais. Porém, a característica especial de uma obra como Ela - Uma Catedral foi que nesse colossal volume a escultura deixou de ser um bloco de matéria para se tornar um espaço interior. Apenas um vazio de órgãos. Um corpo no qual foi possível ingressar. Um território.

A imagem metafórica de um corpo sem órgãos se origina na obra do dramaturgo Antonin Artaud. O autor do manifesto do teatro da crueldade declara guerra aos órgãos na sua obra radiofônica intitulada "Para acabar com o juízo de Deus", que foi transmitida pela primeira vez em 1947: "Cuando ustedes le hayan hecho un cuerpo sin órganos lo habrán liberado de todos sus automatismos y lo habrán devuelto a su verdadera libertad" (ARTAUD, 1975, p. 31). O que Artaud realmente sugeria era o nascimento de um novo corpo, que fosse capaz de experimentar com plenitude a própria vida. Nas suas palavras, os órgãos representavam a funcionalidade, a finalidade e o sentido. Um novo corpo, dizia, que não seja capaz de perceber os limites entre o interior e o exterior, um corpo em expansão. Uma prédica - e no caso de Artaud, também uma prática -, embora tenha sido considerada esquizofrênica pelas autoridades psiquiátricas que o submeteram a dolorosos tratamentos e confinamentos, foi concebida como uma tentativa revolucionária para refazer a vida, um método pedagógico para acordar os corpos anestesiados de uma sociedade que havia sido engessada em condicionamentos e aparências. O novo corpo, para Artaud, era algo que devia ser criado, gestado. "Só que isso não é possível sem antes desconstruirmos o corpo que foi criado para servir docilmente aos poderes do campo social" (SCHÖPKE, 2017, p. 287).

Nessa direção, resultam significativas as reflexões que Gilles Deleuze e Félix Guattari (2012) fazem acerca do corpo. Em Mil Platôs, esses autores argumentam que a multiplicidade é inerente à própria realidade e que não são possíveis de unificar e de totalizar; assim, as multiplicidades estariam em constante tensão com as 
tentativas de estratificação, ou seja, de distribuição dessas multiplicidades segundo uma organização. O corpo enquanto organismo seria uma forma de estratificação, funcionaria como máquina. No entanto Deleuze e Guattari (2012) explicitam que o corpo não é só organismo, o corpo é, ao mesmo tempo, corpo sem órgãos: sem órgãos não de forma concreta como um corpo sem cérebro ou sem pulmão, mas no sentido de não organizado. O corpo sem órgãos são as multiplicidades, são as práticas que desorganizam o organismo, são as experimentações possíveis do corpo.

Deleuze e Guattari (2012) abreviam e designam o corpo sem órgãos como CsO. Ao explicá-lo, os autores explicitam que não se trata de um conceito, mas de práticas que as pessoas podem ter em sua experimentação. Cabe ressaltar que ninguém chega a ter um $\mathrm{CsO}$. As pessoas podem exercitar-se neste sentido, buscar o CsO, mas não se pode efetivamente alcançá-lo, pois ele é multiplicidade pura (totalmente desterritorializada), e isso é inviável - vivemos entre estratificação e multiplicidade, sem nunca chegar a ser só uma dessas coisas.

As práticas de $\mathrm{CsO}$ não são tranquilas, fáceis. Ao mesmo tempo que esse corpo sem órgãos pode ser algo "pleno de alegria, de êxtase, de dança", também podem ser corpos "costurados, vitrificados, catatonizados, aspirados" (DELEUZE; GUATTARI, 2012 , p. 9). Os autores, nesse sentido, chamam atenção para a necessidade de prudência enquanto regra vinculada e imbricada ao próprio exercício de experimentar.

Mas o que é, enfim, o corpo sem órgãos? O que é buscar criar para si, constantemente, um corpo sem órgãos? Deleuze e Guattari apresentam respostas possíveis ao afirmarem que

O CsO é o que resta quando tudo foi retirado. E o que se retira é justamente o fantasma, o conjunto de significâncias e subjetivações. [...] entre um CsO de tal ou qual tipo e o que acontece nele, há uma relação muito particular de síntese ou de análise: síntese a priori onde algo vai ser necessariamente produzido sobre tal modo, mas não se sabe o que vai ser produzido; análise infinita em que aquilo que é produzido sobre o CsO já faz parte da produção deste corpo, já está compreendido nele, sobre ele, mas ao preço de uma infinidade de passagens, de divisões e de sub-produções. Experimentação muito delicada, porque não pode haver estagnação dos modos, nem derrapagem do tipo: o masoquista, o drogado tangenciam estes perpétuos perigos que esvaziam seu CsO em vez de preenchê-lo. (DELEUZE; GUATTARI, 2012, p. 11-2).

Nessa citação, os autores denunciam as possibilidades de fracasso na busca de um CsO. Ao ser ocupado, sempre, por tipos de intensidade, o CsO é capaz 
de produzi-los e reverbera-los. Neste sentido, alguns meios de criar para si um CsO seriam os melhores, como são os casos do masoquista ou do drogado, cujo preenchimento só se dá, respectivamente, por meio das intensidades de dor e das intensidades de frio. O risco de fracasso na criação de um CsO, deste modo, é tornar o CsO vazio, sem que se possa construí-lo como potência.

Para elucidar melhor a questão sobre o CsO, Deleuze e Guattari afirmam, ainda, que não se trata de opô-lo aos órgãos, como se CsO e existência dos órgãos fossem inimigos. Para os autores, "[...] o inimigo é o organismo. O CsO não se opõe aos órgãos, mas a essa organização dos órgãos que se chama organismo" (DELEUZE; GUATTARI, 2012, p. 19). O organismo não é sinônimo de órgãos e, tampouco, sinônimo de corpo. Ele é a estratificação que se coloca sobre o corpo sem órgãos, impondo-lhe modos de ser e se organizar, modos de servir à sociedade como corpo útil. Assim:

O CsO grita: fizeram-me um organismo! dobraram-me indevidamente! roubaram meu corpo! O juízo de Deus arranca-o de sua imanência, e the constrói um organismo, uma significação, um sujeito. É ele o estratificado. Assim, ele oscila entre dois pólos: de um lado, as superfícies de estratificação sobre as quais ele é rebaixado e submetido ao juízo, e, por outro lado, o plano de consistência no qual ele se desenrola e se abre à experimentação. E se o CsO é um limite, se não se termina nunca de chegar a ele, é porque há sempre um estrato atrás de um outro estrato, um estrato engastado em outro estrato. (DELEUZE; GUATTARI, 2012, p. 20).

As artes, como campo do conhecimento, constituem uma área de pesquisas na qual se indagam as formas de experimentar o corpo e, nesse sentido, um caminho metodológico para abordar a multiplicidade inerente nele. Embora alguma estratificação seja necessária para fugir ao caos e à morte, algumas outras limitam o múltiplo de forma nociva. No caso do corpo, os autores pautam a necessidade de prudência nas experimentações, mas ao mesmo tempo argumentam que nossos corpos são capazes de usos que, socialmente, não nos são permitidos. Algumas expressões artísticas contemporâneas pesquisam estes limites entre o aceitável ou inaceitável, indagam nas suas representações sobre os territórios do corpo na sociedade atual. 


\section{DO CORPO FRÁGIL AO INVISÍVEL}

Em 1974, no espaço de arte Studio Morra, em Nápoles, a artista Marina Abramovic realizou uma performance que chamou Rhythm 0. Durante a exibição, Marina permanecia erguida, imóvel e calada em frente ao público, enquanto um cartaz colocado em uma das paredes da sala anunciava: "Nesta mesa há 72 utensílios que podem ser usados sobre mim como se quiser. Eu sou um objeto". Do lado dela, uma mesa com setenta e dois utensílios, entre os quais havia: uma rosa, pão, vinho, uma pluma, perfume, mel, uvas, garfo, faca, bolo, uma barra de metal, tesouras, tinta vermelha, um jornal, uma maçã, tinta branca, um chapéu, uma manta, alecrim, sabão, fio, um prato, navalha, pente, martelo, pregos, um pedaço de madeira, enxofre, azeite, arame, um copo, uma câmera Polaroid e até uma pistola com uma bala. Ao início da performance - ela conta - as pessoas Ihe ofereciam bolo, penteavam seu cabelo, diziam palavras carinhosas enquanto ela continuava estática, firme, impassível. Porém, depois, o clima mudou (Figura 2). Até tiraram suas roupas e começaram a intervir sobre seu corpo como se fosse um objeto.

Figura 2 - Marina Abramovic durante a performance Rhythm 0

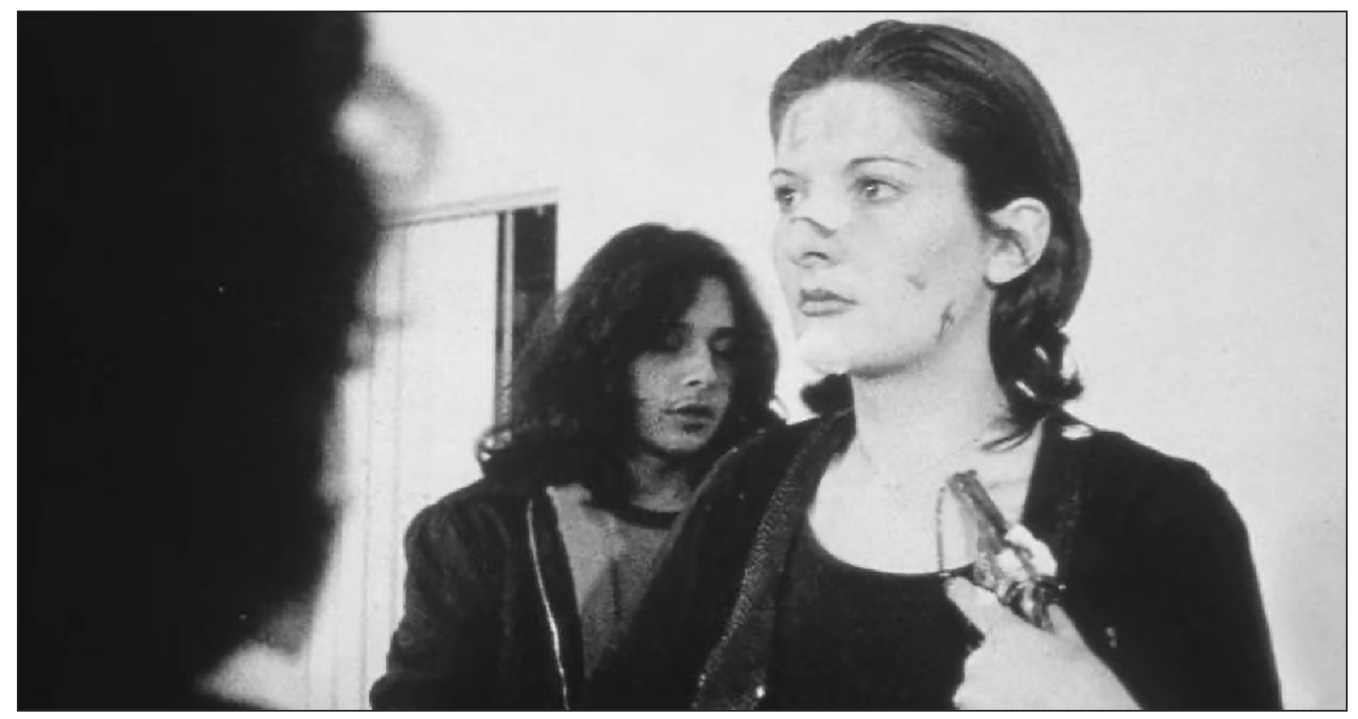

Fonte: Captura de vídeo, Marina Abramovic on performing Rhythm O (1974), MAI- Marina Abramovic Institute. Disponível em https://youtu.be/xTBkbseXfOQ 
Tornaram-se cada vez mais selvagens, fizeram um corte no meu pescoço e beberam meu sangue, me carregaram ao redor e me colocaram acima da mesa e uma pessoa pôs uma faca entre minhas pernas e uma pessoa pegou a pistola, botou a bala e olhou se eu, realmente, com minhas próprias mãos pressionava ao objetivo. ${ }^{2}$ (ABRAMOVIC, 2017, tradução nossa).

Ela relata que, nesses momentos, sentiu muito medo, mas ainda assim quis resistir, porém, algumas notas de jornal registraram que a galeria decidiu interromper a exibição quando haviam transcorrido três horas. Foi quando Marina abandonou sua postura de estátua, escultura, objeto, coisa e caminhou visivelmente consternada. Os agressores não resistiram, não se sabe bem ao quê, mas alguma coisa fez eles reagirem quando aquele corpo estático se revelou humano, pois nesse preciso momento velozmente saíram da sala. "Todos fugiram, as pessoas não conseguiram me enfrentar como uma pessoa"3 (ABRAMOVIC, 2017, tradução nossa).

O corpo de Marina era frágil, imóvel, indefenso, um corpo que não reage, dócil a qualquer tentativa de domínio, inerme diante o uso da força, débil como todo objeto de submissão. A experiência demonstrou que pessoas que aparentam ser pacíficas podem exercer comportamentos violentos se a oportunidade se apresenta. O acontecido revelou a rapidez com que alguém pode decidir ferir a outro quando se acha autorizado e evidenciou até que ponto resulta fácil vitimar alguém que não se defende. Criticada na época como masoquista e exibicionista, Marina continuou expressando a fragilidade do corpo. Os episódios vividos e documentados em Rythym 0 - como se fossem os resultados de um estudo clínico de psicologia social - conseguem instalar a pergunta sobre até que ponto será possível educar para incidir em uma diminuição de condutas agressivas e conscientizar respeito aos territórios do corpo, próprio ou alheio. A experiência vivida pela artista questiona até que ponto um corpo inútil, que não opera, que não serve ou que não se comporta da forma esperada, é objeto de desprezo.

Em definitiva, a performance de Marina situa o corpo na sua dimensão política, desde o momento que revela sua capacidade de gerar dissenso, apenas através de uma postura estática, imobilizada e passiva, um corpo-objeto que, de

2 "Then became more and more wild, they cut my neck and drink my blood, they carry me around put me on the table up in my legs and a person put a knife between my legs and one person took the pistol put the bullet and see if I really with my own hand push the target".

3 "Everybody runs away, people could not actually confront with me as a person". 
alguma forma, tenta resistir aos processos de subjetivação. Porém, da presença firme e polêmica do corpo, nas performances e instalações das artes contemporâneas, passa-se a sua ausência. Em tendências artísticas mais recentes, que podem ser situadas na pós-modernidade, começa a ser expressada a ideia de um corpo que se invisibiliza, implicando que sua dimensão política e seus processos de subjetivação, agora, condensam-se no olhar.

No ano de 2011, inaugurava-se no museu Tate Modern, de Londres, o que seria considerada a maior instalação da artista Yayoi Kusama. Infinity Mirrored Rooms - Filled with the Brilliance of Life, ou Salas Espelhadas Infinitas - Cheias do Brilhantismo da Vida, consistia em uma ampla passarela feita de reflexos que se multiplicavam pelos espelhos enfileirados nas paredes, no teto e na água distribuída simetricamente sobre o chão. Enquanto os visitantes atravessavam a sala, centenas de diminutas luzes de distintas cores se acendiam e desligavam em harmônicas configurações rítmicas. Suas obras chegaram finalmente ao Brasil em 2014, para sua exposição Obsessão Infinita, que teve lugar no Instituto Tomie Ohtake, em São Paulo. A palavra infinito aparece com insistência nas mostras de Yayoi, as quais retratam o que ela chamou de obsessões, que se manifestam através da repetição insistente de certos padrões de desenho, os quais se reproduzem sobre diversas superfícies, diluindo contornos e camuflando formas volumétricas que somem devoradas por uma inquietante sensação de vazio. 0 mesmo efeito se projeta sobre o próprio corpo físico da artista, quando aparece, nas suas instalações e performances, submergido em um mar de bolinhas, sejam tridimensionais, sejam planas ou virtuais (Figura 3). 
Figura 3 - Artista Yayoi Kusama na Sala de Estar/Árvore Amarela (2002)

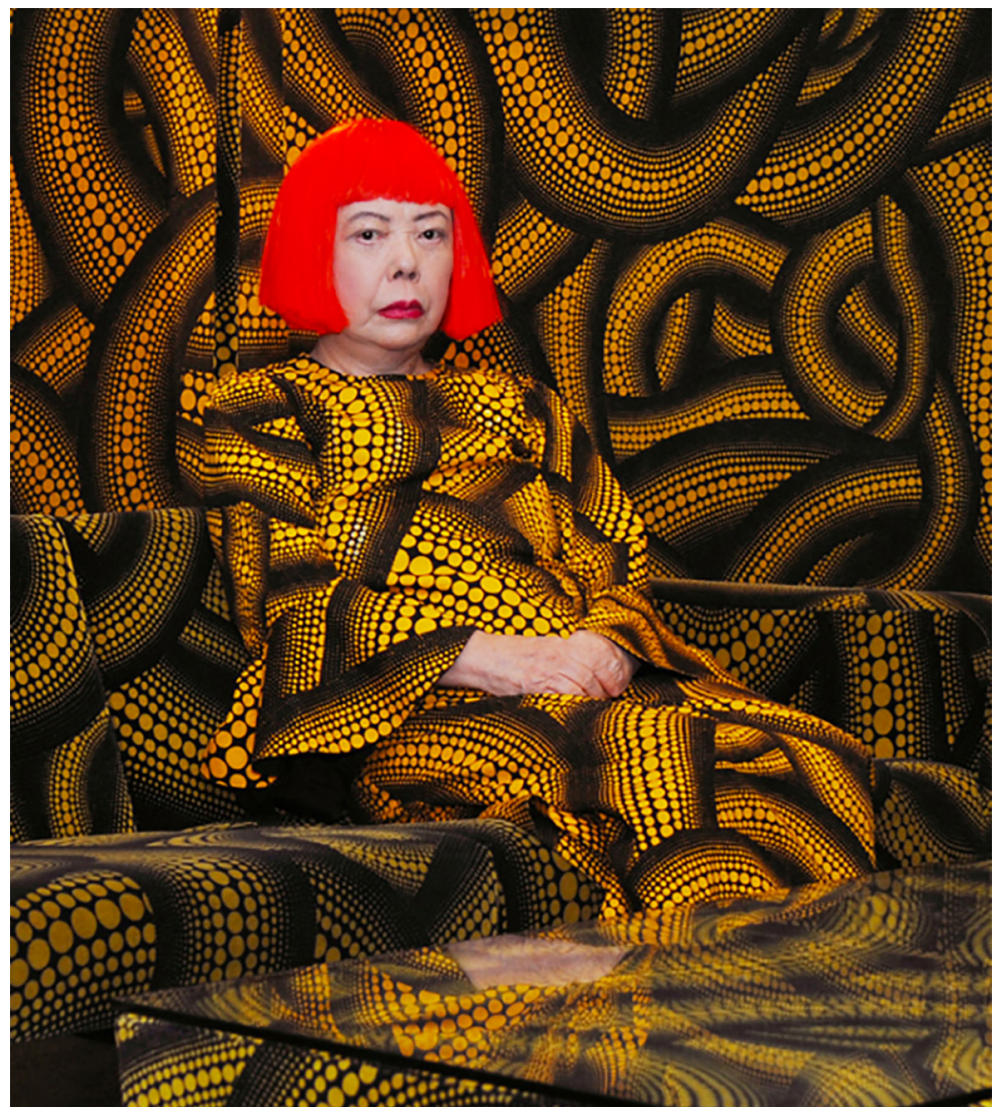

Fonte: Kusama in Living Room, Graf Studio, Osaka, 2002. Disponível em: https://hirshhorn.si.edu/kusama/yayoi-kusama/

$\mathrm{Na}$ imagem de Yayoi, o corpo se invisibiliza, integra-se de tal maneira ao entorno, que desaparece. Uma metáfora contemporânea para situar os novos territórios do corpo líquido, fluido, que pareceria ter superado a dureza de sua estrutura, sumindo em um espaço infinito e homogêneo. Deixou de ser frágil ou dócil, o corpo agora se tornou invisível.

Yayoi passou boa parte da sua vida em internações psiquiátricas, Artaud também. Cabe perguntar se realmente teriam sido crises paranoicas ou estados de alienação mental o fato que esses artistas tivessem experimentado, de alguma forma, que seus próprios corpos não Ihes pertenciam. Artaud sentia que seu corpo 
não estava ao serviço dos seus próprios desejos, anseios ou necessidades, como se tivesse sido condicionado a cumprir funções do corpo social. Por isso declara guerra aos órgãos, ou seja, à funcionalidade do organismo, aos condicionamentos impostos.

No caso de Yayoi, o corpo finalmente se desintegra, desaparece, funde-se com o entorno. Talvez foi uma forma de denunciar a perversa pretensão, que resiste no imaginário da globalização, de uma sociedade homogênea. "As minorias e as maiorias não se distinguem pelo número. Uma minoria pode ser mais numerosa que uma maioria. O que define a maioria é um modelo ao qual é preciso estar conforme" (DELEUZE, 1992, p. 214). Será esse modelo - do qual fala Gilles Deleuze - o desenho padrão que se multiplica sobre o corpo da artista? O certo é que dos velhos métodos disciplinares da modernidade, consagrados ao adestramento dos corpos dóceis, passou-se, na atualidade, a uma organização baseada no controle.

Os espaços de confinamento como escola, fábrica ou prisão, onde os corpos se disciplinavam, deixaram de ser necessários. A densidade da população e seus constantes deslocamentos os tornou insuficientes e ineficazes. "Encontramo-nos numa crise generalizada de todos os meios de confinamento, prisão, hospital, fábrica, escola, família" (DELEUZE, 1992, p. 220). O corpo do sujeito contemporâneo já não precisa permanecer dentro do recinto delimitado de uma instituição para ser vigiado e controlado. Os cenários da literatura fantástica que assombrava com descrições de futuros distópicos, em que os seres humanos eram permanentemente observados por câmeras, viraram rotina na vida contemporânea. $O$ sujeito se desloca, goza de uma aparente liberdade, apenas enquanto permanece monitorado, inspecionado e fiscalizado. A silhueta de Yayoi coberta por inúmeras bolinhas, tal como aparece em suas performances e instalações, transformou-se em uma emblemática metáfora da existência contemporânea, na qual os corpos deixaram de ser corpos, para serem desarticulados em uma somatória de dados e algoritmos.

Do mesmo modo que é possível desconstruir visualmente a figura humana, também é viável engendrá-la. Ingressando na pós-modernidade, a cultura visual define seus territórios sob o eixo visibilidade-invisibilidade. "La cultura visual no depende de las imágenes en sí mismas, sino de la tendencia moderna a plasmar en imágenes o visualizar la existencia" (MIRZOEFF, 2003, p. 23). A visibilidade 
define os territórios da existência. Será que realmente existe aquilo que não se enxerga? Na pós-modernidade, a resposta é fácil: não. As novas tecnologias da informação têm aumentado a capacidade de visualização, produção e circulação de imagens. Um mundo de realidades virtuais composto por imagens fixas ou em movimento que, pela velocidade em que são interpretadas e compartilhadas, embora fugazes e planas, apresentam-se como um devir contínuo que o sujeito absorve sem tempo de avaliar. "Asistimos hoy al paso de la cultura moderna del cálculo a la cultura posmoderna de la simulación" (ZIZEK, 2006, p. 218). Assediado por estímulos visuais, o sujeito recria a ilusão de pertencer ao mundo pelo simples fato de assimilar sensorialmente a experiência através de um universo virtual, mas sem se envolver nele, resultando impossível estar fisicamente em todos os lugares; a tecnologia comuta a frustração de uma experiência incompleta pelo placebo de um intercâmbio virtual.

Con el surgimiento de la realidad virtual y de la tecnología, asistimos a la desaparición del límite que separa lo interior de lo exterior. Dicha desaparición pone en peligro nuestra percepción más elemental de lo que es nuestro propio cuerpo y la relación que mantiene con su entorno; entorpece nuestra actitud fenomenológica habitual hacia el cuerpo de otra persona [...] cuando nos sumergimos directamente en la realidad virtual, perdemos contacto con la realidad, es decir, las ondas eléctricas no interactúan con nuestro cuerpo a nivel externo sino que atacan directamente a nuestros sentidos: hoy día el globo ocular engloba al cuerpo entero. (ZIZEK, 2006, p. 222).

A artista brasileira Cibelle Cavalli Bastos discute a problemática da visibilidade ou invisibilidade. Ser visto dá ao corpo a dimensão do reconhecimento e da existência em uma sociedade na qual os processos, disciplinares e de controle, pareceriam se concentrar agora em operar sobre uma função específica do organismo humano: a visão (Figura 4). 
Figura 4 - Detalhe da obra Is a feeling de Cibelle Cavalli Bastos

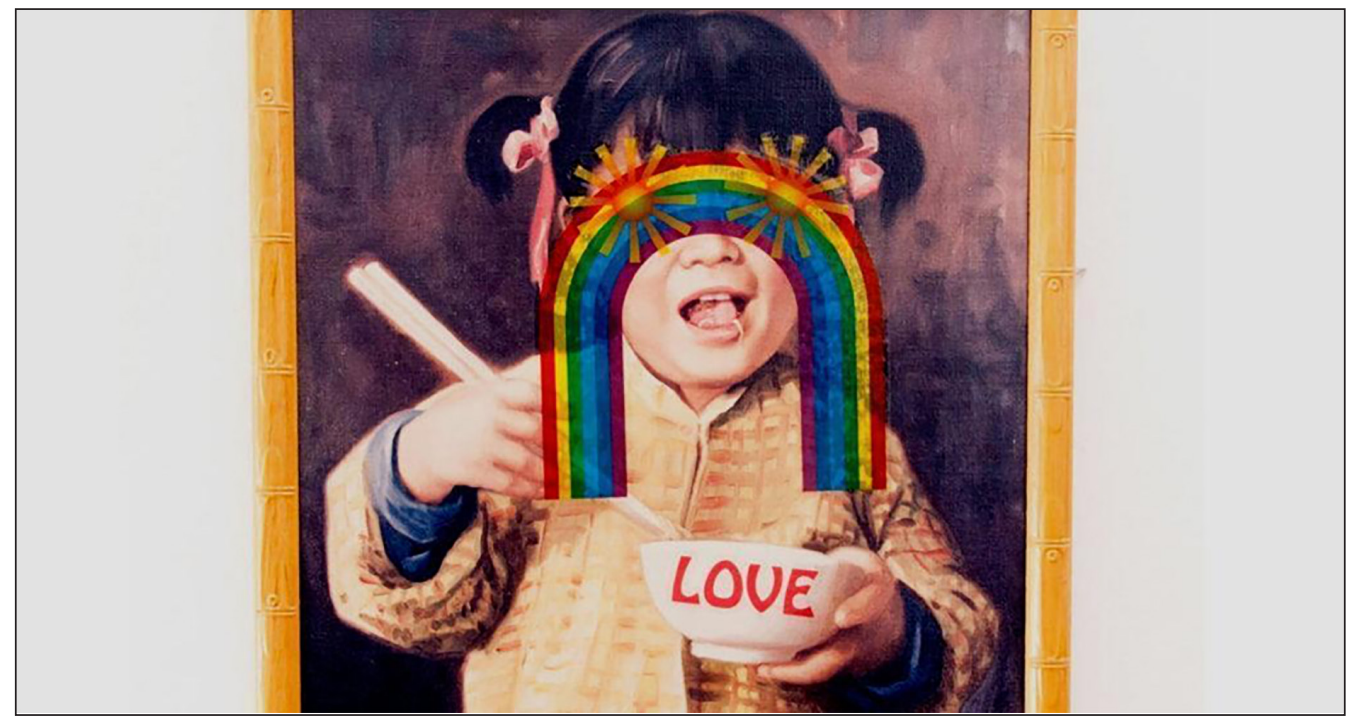

Fonte: Obra Is a feeling de Cibelle Cavalli Bastos, materiais diversos, 55 × 45 cm, 2013; mostra Queermusem - Cartografias da Diferença na Arte Brasileira. Disponível em: https://revistacult.uol.com.br/home/queermuseu-santander-cultural-luiz-camillo-osorio/

Regular a circulação de imagens significa incidir sobre o que pode ser visto, olhado, considerado ou analisado. Em outras palavras, a ação de censurar, de controlar aquilo que é apresentado ao público, de determinar que se pode ou não exibir, implica criar condicionamentos nas competências visuais do sujeito. De fato, a obra de Cibelle, junto de uma ampla seleção de trabalhos que versavam sobre a temática queer, foi censurada. A mostra de artes visuais intitulada Queermusem - Cartografias da Diferença na Arte Brasileira, inaugurada em agosto de 2017 nas salas do Santander Cultural, em Porto Alegre, foi suspensa na quarta semana depois de ter sido inaugurada. Com curadoria de Gaudêncio Fidelis, as obras selecionadas e apresentadas abordavam a temática queer, a diversidade sexual e as questões de gênero, desde uma perspectiva histórica, abrangendo desde meados do século XX até os dias atuais, no olhar de 85 artistas. $O$ ato de censura, nesse caso, não proveio do Estado, mas da própria instituição organizadora que, pela pressão exercida por grupos políticos e religiosos, decidiu interromper a mostra e retirar a exposição. 
A revolta contra uma exposição de arte pareceria anacrônica em tempos em que tanto crianças, jovens ou adultos gozam de amplos acessos a todo tipo de conteúdo visual que circula na web. Embora a disseminação desses conteúdos se propague com fluidez nos espaços privados, ou seja, nas telas de qualquer dispositivo, existe um claro consenso nos setores conservadores da sociedade tal como se evidenciou no fechamento da exposição Queermuseum - de que tais imagens não deveriam ser visibilizadas através de âmbitos institucionais.

O controle institucional sobre o olhar também operou em um episódio recente à escrita deste artigo. No dia 24 de agosto de 2021, o videoclipe da canção Etérea foi apresentado durante uma aula de artes na Escola Municipal Pascoal Meller, para uma turma de nono ano do Ensino Fundamental, com estudantes entre 14 e 15 anos. O clipe oficial da canção Etérea, de autoria do compositor Criolo, consistia na apresentação performática de uma sucessão de corpos dançando, que se identificavam como personagens e personalidades dos coletivos sociais LGBTI. Assim como na música, o autor desejava quebrar o binarismo dos ritmos, fusionando batuque com eletrônica, nas imagens visuais se pretendia romper com o binarismo sexual exibindo as diversas manifestações identitárias e estéticas do corpo. "É necessário quebrar os padrões, é necessário abrir discussões", versa a própria letra da canção. Porém, os padrões, dessa vez, recrudesceram-se sobre o corpo do professor que apresentou o videoclipe na sala de aula, quando foi seguidamente-e por essa única causa - exonerado do cargo pelo prefeito de Criciúma, quem destacou que não permitiria viadagem nas escolas, segundo informaram diversos meios de imprensa. A reação dele e a do secretário de educação do município deixariam claro que o objetivo da punição e da censura não eram os aspectos explícitos das imagens exibidas, mas a mensagem política e social que elas carregavam. Não foi que circulasse nas plataformas digitais e de streaming um vídeo com reivindicações de conteúdo subversivo o que determinou a reação das autoridades locais, mas o fato de que essas reivindicações, através de uma expressão artística como a música, pudessem ter conquistado visibilidade nos espaços escolares.

O conceito de corpo sem órgãos implica um rompimento com a estratificação, ou seja, uma quebra com as tentativas de organizar - ou limitar - a multiplicidade. Se compreende que a estratificação do corpo como organismo está, em nossa sociedade, vinculada ao ideal de corpo cisheteronormativo. A cisheteronormatividade faz parte da estratificação dos corpos ao determinar as partes e 
as funções do corpo que se chama mulher e do que é denominado homem. Essa é a crítica feita por grande parte dos estudos feministas que questionam uma visão biológica do que seria homem ou mulher. Judith Bulter (2018) vai ainda além e problematiza todo o entendimento do gênero como identidade essencial ou inerente ao indivíduo, compreendendo o gênero não de forma fixa ou estável, mas múltipla e mutável, de acordo com os diferentes contextos sócio-históricos e discursivos nos quais os sujeitos estão inseridos. Para a autora:

$O$ fato de a realidade do gênero ser criada mediante performances sociais contínuas significa que as próprias noções de sexo essencial e de masculinidade ou feminilidade verdadeiras ou permanentes também são constituídas, como parte da estratégia que oculta o caráter performativo do gênero e as possibilidades performativas de proliferação das configurações de gênero fora das estruturas restritivas da dominação masculinista e da heterossexualidade compulsória. (BUTLER, 2018, p. 244).

A partir dessa desestabilização do sexo, do gênero e da sexualidade, Butler (2018) traz um entendimento do corpo não enquanto uma entidade, mas enquanto espaço historicizado, espaço de ações e de relações. Essa autora é uma referência da chamada perspectiva epistemológica queer, que se desdobra em vários pensadores e várias pensadoras, cujas reflexões vêm problematizar a cisheteronormatividade.

Não seria possível obviar que, na realidade atual das escolas e nas práticas curriculares, veiculam-se discursos nos quais funcionam estratégias de poder que querem normalizar e disciplinar os corpos a partir de uma norma heterossexual e cisgênera. É neste sentido que, muitas vezes, as discussões de gênero e sexualidade são tidas como perigosas dentro do espaço escolar, assustando professores e professoras que temem sofrer retaliações caso abordem tais temáticas em suas práticas docentes. No entanto, isso não significa dizer que na escola não existam formas de resistência ou presença de corpos queer que incidam nos currículos. Não significa dizer que não há docentes comprometidos com o debate de gênero e sexualidade, pois sem dúvida há - neste artigo, uma das autoras é professora da educação básica e assume tal compromisso. A escola é, ao mesmo tempo, espaço de cisheteronormatividade e um espaço outro, que permite que se encontrem brechas para a busca da liberdade.

Nesse contexto, as artes não deveriam ser pensadas só como uma disciplina, como apenas um espaço confinado dentro da organização curricular da escola. As expressões artísticas, em suas variadas formas, com frequência representam 
olhares sobre os territórios do corpo, significam pesquisas sobre seus espaços, implicam indagações sobre os alcances das suas manifestações. Nesse sentido, os trabalhos desenvolvidos por artistas se erguem como exemplos, como pontos de partida para refletir em uma sala de aula acerca desta temática. Em definitiva, a arte em si mesma, em suas distintas linguagens, poderia ser definida como um território que permite aos corpos se manifestarem como corpo sem órgãos, como desestabilização da estratificação, como experimentação.

\section{CONSIDERAÇÕES FINAIS}

Ressignificar o corpo, seus sentidos, percepções, emoções, seus desejos, seus cuidados, seus prazeres, seus usos no espaço e no tempo, reconhecer o outro, os outros, através de uma compreensão dos territórios do corpo, suas representações, aparências, comportamentos e, portanto, reduzir a violência, seja física, seja simbólica ou psicológica, são desafios pedagógicos cruciais do âmbito escolar.

Independentemente da discussão sobre se tal ou qual imagem deva ser ou não mostrada aos estudantes - já que toda ação de ensino demanda uma seleção de matérias e conteúdos -, utilizar produções e propostas do campo das artes visuais como ferramentas pedagógicas oferecerá sempre a vantagem de contar com material visual que não direciona seus significados em um sentido único, mas que apela por um leque de conexões com outros dados, informações e fatos da experiência.

Das discussões realizadas neste artigo a partir do conceito de corpo sem órgãos e sua relação com práticas de liberdade, desterritorialização e desestratificação do corpo - sobretudo de um corpo que pode encontrar formas de romper com os desígnios da cisheteronormatividade -, desprende-se que a escola é um espaço que pode possibilitar tais práticas, a começar da inserção de experiências artísticas no cotidiano.

As propostas educativas deveriam contemplar as circunstâncias específicas em que a cultura opera, com a conviç̧ão de que só desde um conhecimento das condições em que a existência se desenvolve é que a educação poderia construir aprendizagens e gerar ações que incidam na vida humana. 


\section{REFERÊNCIAS}

ABRAMOVIC, Marina. Marina Abramovic on performing Rhythym 0 (1974). Marina Abramovic Institute, 2017. Disponível em: https://youtu.be/xTBkbseXfOQ. Acesso em: 21 ago. 2021.

ARTAUD, Antonin. Para terminar con el juicio de dios y otros poemas. Buenos Aires: Ediciones Caldén, 1975.

BUTLER, Judith. Problemas de gênero: feminismo e subversão da identidade. Rio de Janeiro: Civilização Brasileira, 2018.

DELEUZE, Gilles. Conversações 1972-1990. São Paulo: Editora 34, 1992.

DELEUZE, Gilles; GUATTARI, Félix. Mil Platôs. São Paulo: Editora 34, 2012. V. 3.

FOUCAULT, Michel. Microfísica do poder. Rio de Janeiro/São Paulo: Paz e Terra, 2018.

FOUCAULT, Michel. Em defesa da sociedade: curso no Collège de France (1975-1976). São Paulo: Martins Fontes, 2010.

FOUCAULT, Michel. Vigiar e punir: nascimento da prisão. Petrópolis: Editora Vozes, 1997.

MONDZAIN, Marie-José. Nada, tudo, qualquer coisa: ou a arte das imagens como poder de transformação. In: NAZAR, Leonor; SILVA, Rodrigo (Org.). A república por vir: arte, política e pensamento para o século XXI. Lisboa: Fundação Calouste Gulbenkian, 2011. p. 103-28.

MIRZOEFF, Nicholas. Una introducción a la cultura visual. Barcelona: Paidós, 2003.

SCHÖPKE, Regina. Corpo sem órgãos e a produção da singularidade: a construção da máquina de guerra nômade. Revista de Filosofia Aurora, Curitiba, v. 29, n. 46, p. 285305, jan./abr. 2017.

ZIZEK, Slavoj. Lacrimae rerum: ensayos sobre cine moderno y ciberespacio. Barcelona: Random House Mondadori, 2006.

\section{Sobre os autores:}

Sabina Sebasti: Doutoranda em Educação pela Universidade Federal de Pelotas (UFPel). Bolsista CAPES. Mestre em Artes Visuais pela UFPel. Graduada em Licenciatura em Artes Plásticas y Visuales pela Universidad de la Republica Uruguay 
(UDELAR). Artista Visual. Docência em Nível Superior em Artes pela UDELAR. Professora no curso Bacharelado em Produção e Política Cultural na Universidade Federal do Pampa. Formação interdisciplinar em Avaliação de Metodologias de Ensino. Pesquisadora em Educação Artística, com especial interesse em desenvolvimento de metodologias experimentais. E-mail: sabinasebasti@gmail.com, Orcid: https://orcid.org/0000-0002-8819-6727

Ana Gabriela da Silva Vieira: Doutoranda em Educação na linha de Epistemologias Descoloniais, Educação Transgressora e Práticas de Transformação na Universidade Federal de Pelotas (UFPel). Mestre em Educação na linha de Epistemologias Descoloniais, Educação Transgressora e Práticas de Transformação pela UFPel. Graduada em História - Licenciatura pela UFPel. E-mail: anahisufpel@gmail.com, Orcid: https://orcid.org/0000-0002-8962-5108

Márcio Caetano: Pós-doutor em Currículo e Narrativas Audiovisuais, com apoio do PNPD-CAPES, pela Universidade do Estado do Rio de Janeiro (UERJ). Doutor e mestre em Educação pela Universidade Federal Fluminense (UFF). Graduado em História pela UERJ. Coordenador do Centro de Memória LGBTI João Antônio Mascarenhas (UFPEL/FURG/UFES/UFOB). Docente na Faculdade de Educação e do Programa de Pós-Graduação em Educação da Universidade Federal de Pelotas (UFPel). Colaborador no Programa de Pós-Graduação em Educação em Ciências da Universidade Federal do Rio Grande (FURG).E-mail: mrvcaetano@gmail.com, Orcid: https://orcid.org/0000-0002-4128-8229

\section{Recebido em: 09/09/2021 Aprovado em: 15/10/2021}


